\title{
Reservoir potential of the Haymana Formation submarine-fan sandstones in the Haymana Basin of Turkey
}

\author{
Aylin Gecer $^{1} \cdot$ Aynur Buyukutku $^{2}$ (1) $\cdot$ Paulo S. Caetano ${ }^{3} \cdot$ Fernando T. Rocha $^{4} \cdot$ Mithat E. Kıbrıs $^{2} \cdot$ Mustafa Albayrak $^{5}$
}

Received: 19 March 2019 / Accepted: 17 April 2019 / Published online: 22 April 2019

(c) The Author(s) 2019

\begin{abstract}
Sedimentological and petrographic studies of the Haymana Formation sandstones identify a submarine fan in the Haymana Basin. This study is confined to outcrop samples from the submarine-fan sandstones (the L1, L2, and L3 sections) and focuses on documentation of the petrographic characteristics of and depositional controls on reservoir properties of the Haymana Formation sandstones. Analysis of the lithology, texture, sedimentary structure, and petrography of the outcrop samples allows separation of the Haymana Formation sandstones into three distinct lithofacies, A, B, and C. Lithofacies A sandstones exhibit medium-coarse grain sizes $(0.4-0.6 \mathrm{~mm})$, moderate-good sorting, and subrounded grains. Lithofacies B sandstones exhibit fine grain sizes $(0.2 \mathrm{~mm})$, moderate sorting, and subrounded-subangular grains. Lithofacies $\mathrm{C}$ sandstones exhibit very fine grain sizes $(0.112 \mathrm{~mm})$ and nonreservoir facies. The main aim of this study is to document the diagenetic history and reservoir quality of the Haymana Formation sandstones. Lithofacies A has the best permeability, ranging from 80 to $120 \mathrm{mD}$, which can be related to the large grain size, the presence of cross-bedding, small amount of authigenic clays or cements in the pore throats, and enlarged pore apertures. In contrast, Lithofacies B sandstones contain variable yet small pore and pore-throat sizes, which are affected by abundant pore-filling authigenic clays, small grain sizes, and no dissolution. The permeability of the Lithofacies B sandstone ranges from 16 to $35 \mathrm{mD}$, which is lower than that of the Lithofacies A sandstone. Additionally, the Lithofacies B sandstones have small median pore-throat sizes $(\mathrm{mean}=1.52 \mu \mathrm{m})$ and low porosities (average 4-6\%), and the Lithofacies A sandstones have large pore-throat sizes (mean $=2.06-3 \mu \mathrm{m})$ and high porosities (average 20-25\%), with most pore throats (50\% or more) ranging between 1 and $4 \mu \mathrm{m}$. According to these data, the Lithofacies A sandstones show good reservoir characterisation. To date, significant hydrocarbon deposits have not been discovered in the Haymana Formation sandstones, although intensive exploratory work towards this end has been carried out in the Haymana Basin. According to this study, the proximal sandstones of the submarine-fan complex of the Haymana Formation may contain high-potential reservoirs in the Haymana Basin. In the basin, hydrocarbon is sourced from deep zones and may be capped by the proximal part of the Haymana Formation sandstones. According to this study, the Lithofacies B sandstones of the Haymana Formation are not suitable as diagenetic traps for hydrocarbon exploration in the Haymana Basin. However, the Lithofacies A sandstones may be expected to have the highest exploration success.
\end{abstract}

Keywords Reservoir $\cdot$ Submarine fan $\cdot$ Hydrocarbon $\cdot$ Cementation $\cdot$ Porosity $\cdot$ Permeability $\cdot$ Pore throat $\cdot$ Fourier transform infrared (FTIR)

Electronic supplementary material The online version of this article (https://doi.org/10.1007/s13202-019-0666-1) contains supplementary material, which is available to authorized users.

Aynur Buyukutku

mxwb2448@yahoo.com

1 Department of Chemical Engineering, Engineering Faculty, Tandoğan Campus, Ankara University, 06100 Ankara, Turkey

2 Department of Geological Engineering, Engineering Faculty, Gölbaşı Campus, Ankara University, 06830 Ankara, Turkey
3 Sciences and Technology Faculty, New University of Lisbon, 2829-516 Caparica, Portugal

4 Department of Geosciences, Geobiotec Research Centre, Aveiro University, 3810 Aveiro, Portugal

5 General Directorate of Mineral Research and Exploration, 06800 Ankara, Turkey 


\section{Introduction}

Haymana Basin is located in Central Anatolia and covers approximately $4000 \mathrm{~km}^{2}$ (Fig. 1). Haymana Formation sandstones are exposed in the Haymana Basin around Haymana vicinity, southwest of Ankara in Central Anatolia, Turkey (Fig. 2). Although the evolutionary history of the basin is directly connected with crystalline rocks of the Pontide, Tauride, and Kırşehir blocks, only Pontide basement is exposed in the study area while Kirşehir or Tauride basement bounds the basin to the east and south without any direct contact (Fig. 1). The basement units exposed in the study area cover small areas with respect to basin fill and generally have tectonic contact with the younger units in the north and south. In contrast to the complex structure of the basement units, the basin fill was continuously deposited from the Upper Cretaceous to Upper Eocene time interval and is basically represented by continental clastic rocks, shallow-marine limestones, and turbidites. The basin fill and the basement units are unconformably covered by Neogene continental clastics or evaporites.

Deposits exposed in the Haymana Basin can be separated as follows: (1) basement, (2) Upper Cretaceous to Eocene basin fill, and (3) Neogene cover (Fig. 3).
Fig. 1 Research area and some of the interpreted major structures of Central Anatolia, from the Pontides in the north and Taurides in the south (interpreted on 1:500 000 geological map of the MTA), DF: Dereköy Fault, KF: Kalecik Fault, SKFZ: Sungurlu-Kırıkkale Fault, SLFZ: Salt Lake Fault Zone

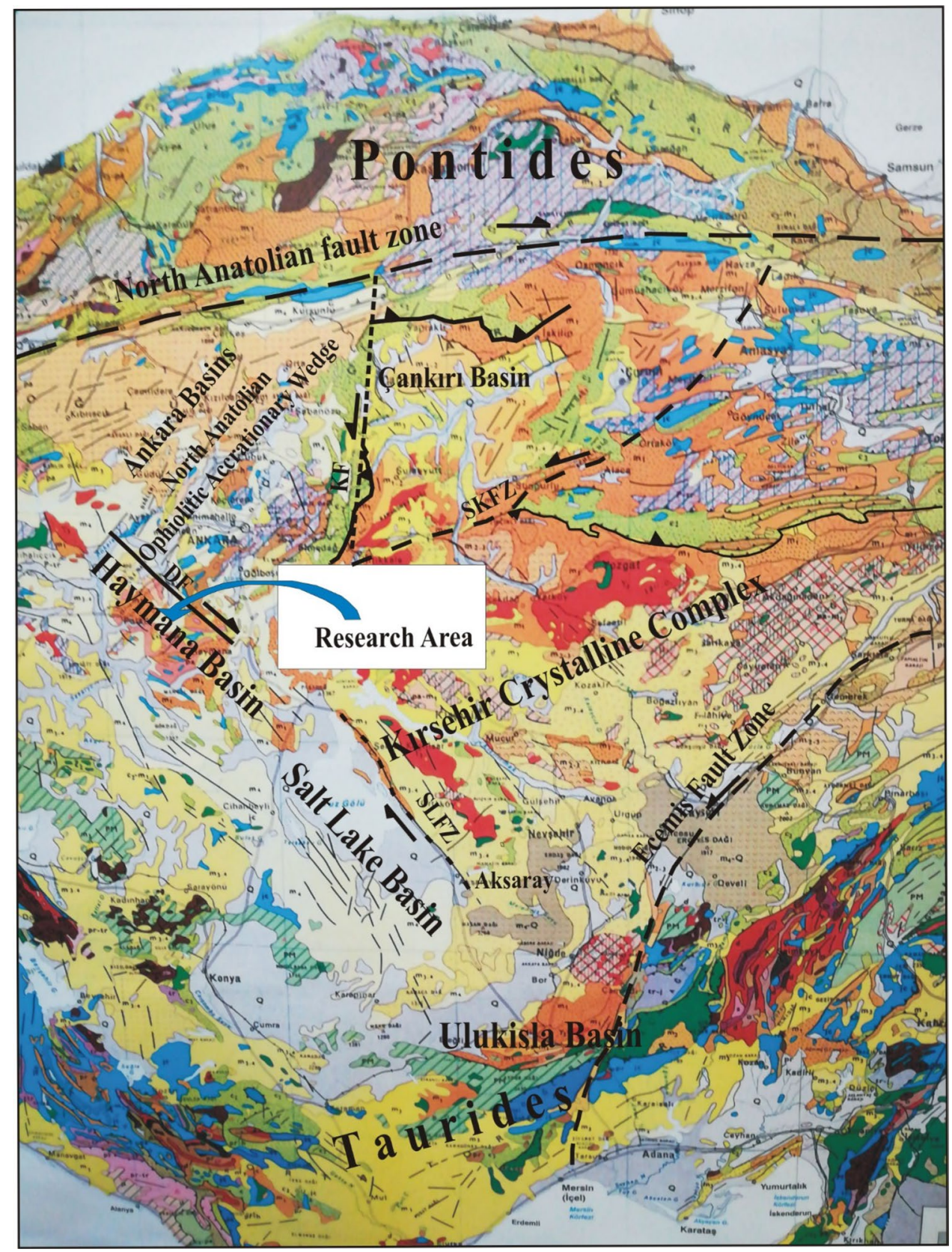




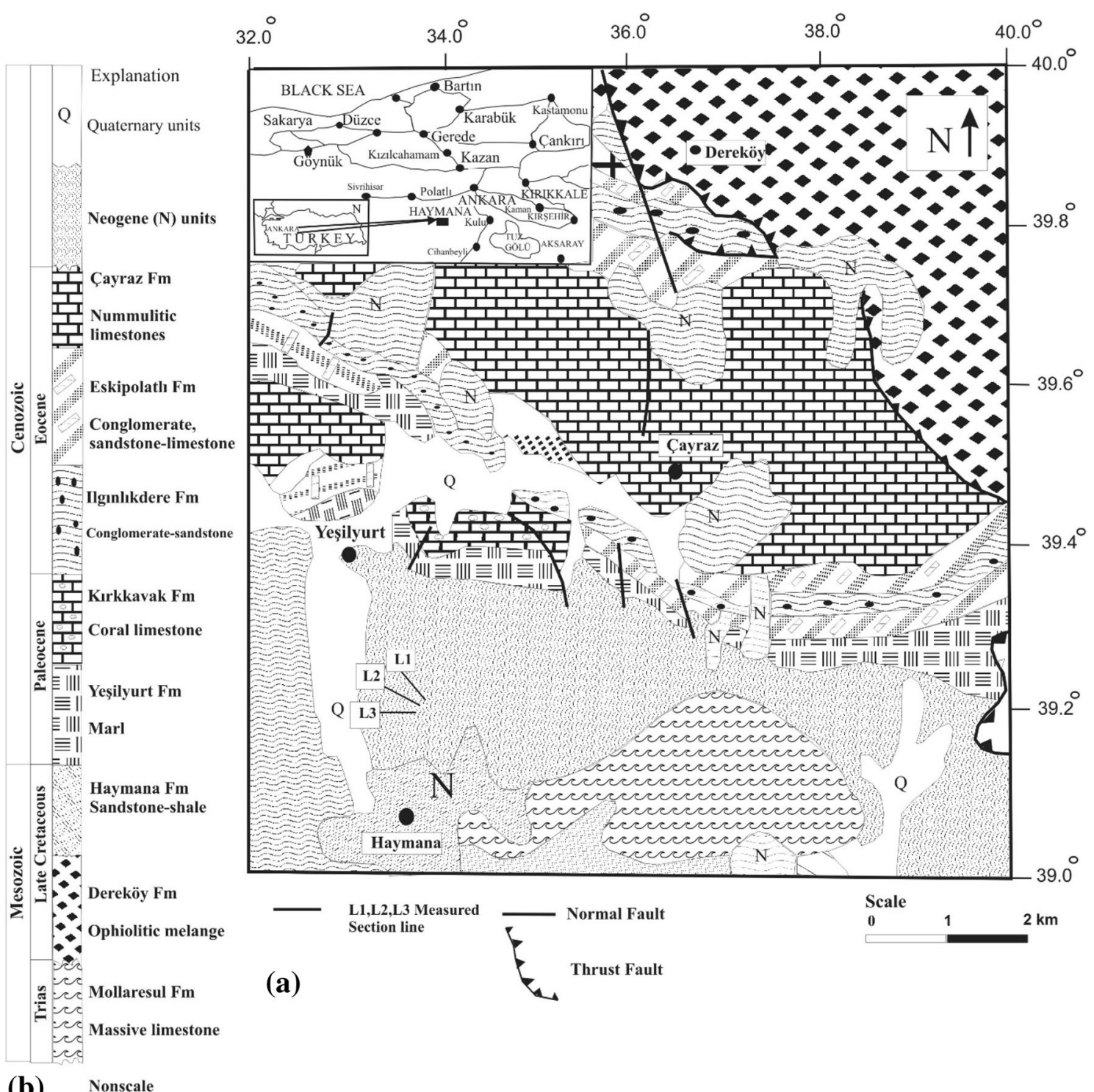

(b) Nonscale

Fig. 2 Location map (a) explanation (b) of the surrounding around of the Haymana vicinity, southwest of Ankara. Modified from Ciner et al. (1996)

Submarine fans are the most important type of petroleum reservoir in the world. Submarine fans can also be prolific hosts for oil and gas resources (Pettingill and Weimer 2002). Approximately 58 billion barrels of oil equivalent have been discovered in water depths $>500 \mathrm{~m}$ from 18 basins on six continents as of 2002 (Pettingill and Weimer 2002). Most resources have been found in the Gulf of Mexico, offshore Brazil, and offshore West Africa (Pettingill and Weimer 2002). Therefore, the presence of hydrocarbon-saturated deep channels in the turbiditebearing Haymana Formation has palaeogeographic significance and will also attract the attention of oil companies searching for commercial hydrocarbons in unexposed parts of the Haymana Basin.
The Haymana Basin is important because of its location, sedimentary fill, and organic-rich shales in deep zones and the residual oil at the surface of the Upper Cretaceous Haymana sandstones (Fig. 3). Oil-bearing sandstones of the Haymana Formation in the area indicate that the residual oil was probably derived from deep zones NW, $\mathrm{E}$, and NE of the Haymana vicinity. In this basin, hydrocarbons from deep zones may be capped by the Haymana sandstones (Ates et al. 2005). Büyükutku and Sarı (2011) documented the reservoir properties of Haymana Formation sandstones in the Salt Lake Basin (Fig. 1). The porosities in the Haymana Formation sandstones in this basin range up to $28.5 \%$, while the permeability is mostly less than $0.01 \mathrm{mD}$. Sonel et al. (2009) worked on framework 


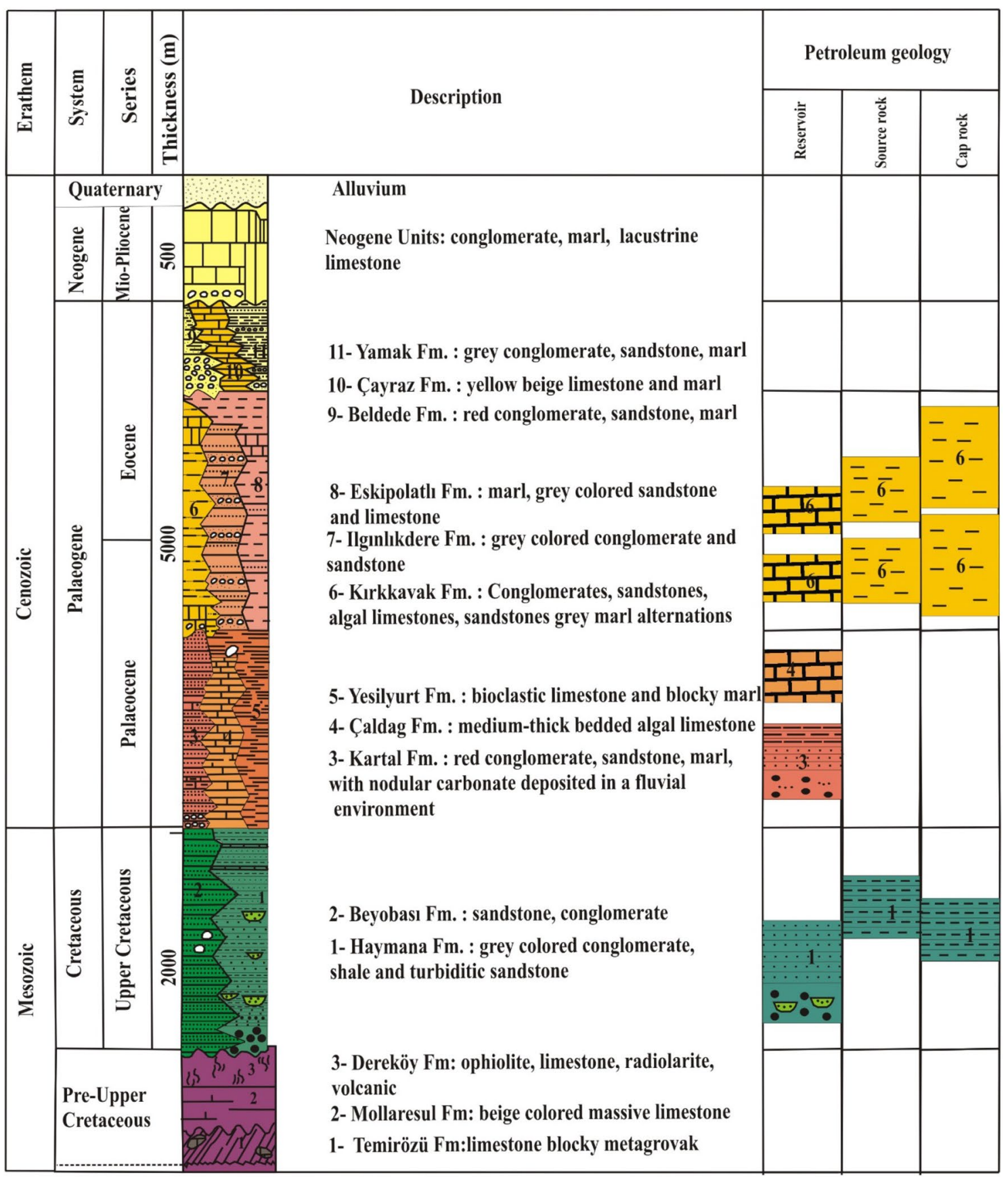

No scale

Fig. 3 General stratigraphic column section of the Haymana Basin. Modified after Ünalan et al. (1976 and Sirel et al. (1986). Fm-Formation

petrography and provenance studies on the Upper Cretaceous sandstones of the Ereğli-Ulukışla Basin in Central Anatolia (Fig. 1). The Upper Cretaceous Haymana Formation is time equivalent to the Çiftehan Formation in the Ereğli-Ulukışla Basin. The average porosity values of the Çiftehan Formation sandstones range from 1.96 to $5 \%$. Permeability values of less than $1 \mathrm{mD}$ indicate that these sandstones display poor reservoir quality. It should be noted that in previous studies, Upper Cretaceous Haymana Formation sandstones have not been researched in terms of reservoir properties in the Haymana Basin.

Three stratigraphic sections (L1, L2, and L3) were measured around Haymana vicinity (Fig. 2). Sedimentation was controlled by turbidity currents with at least two sets of thick, conglomerate, conglomerate-sandstone, and sandstone-shale alternation deposits at the base of fining-upward 
sequences possibly resulting from abrupt activities of submarine fans.

The major objective of this investigation was to document the structure, texture, diagenetic history, and reservoir quality of the Haymana sandstones. Specific objectives were to (1) determine the mineralogical composition of the sandstones, (2) synthesise a general diagenetic sequence of the Haymana sandstones, (3) determine the petrophysical parameters (porosity, permeability, and capillary pressure) to interpret reservoir quality of the Haymana Formation sandstones, (4) investigate the presence of hydrocarbons in these sandstones and the relationship between the absorbance of hydrocarbon functional groups and permeability (5) determine the effect of clay minerals on reservoir quality, and (6) suggest a sedimentological model for hydrocarbon exploration.

The Haymana Formation shows submarine-fan properties, and the present study is confined to outcrop samples from the submarine-fan sandstones (the L1, L2, and L3 measured sections). The sandstone formation is classified into three lithofacies on the basis of texture and mineralogy. This paper focuses on documentation of petrographic characteristics of and depositional controls on reservoir properties. Extensive study of the diagenesis of the Haymana sandstones has established petrographic, diagenetic, and porosity-permeability trends, and these studies have advanced our understanding of the occurrence and quality of surface reservoirs. In the Haymana Formation, diagenetic processes active during the burial history of the Upper Cretaceous sandstones were responsible for modifying the reservoir properties. Knowledge of when and to what degree these diagenetic processes affected reservoir development can be helpful in predicting the areal development of reservoir quality and inferring potential production characteristics. Understanding the sedimentological model and the distribution of diagenetic alterations and their impact on reservoir quality is a key for developing a petroleum field.

\section{Geological setting and stratigraphy}

The pioneering studies of the Haymana Basin were conducted by Chaput (1932, 1935a, b, 1936), Rigo de Righi and Cortesini (1959), Reckamb and Özbey (1960), and Schmidt (1960). Although the basic goal of these studies was to reveal the petroleum potential of the basin, they established a stratigraphic framework for the region, and the following studies by Yüksel (1970), Sirel (1975) and Ünalan et al. (1976) formed the current stratigraphic nomenclature for the region.

Sirel (1975) studied the micropalaeontology of the Upper Cretaceous-Eocene units and determined foraminiferal biozones for that time interval. Ünalan et al. (1976) studied the
Haymana and Polatlı region and defined the stratigraphy of the region. Ünalan et al. (1976), Batman (1978), Dellaloğlu and Aksu (1991), and Rojay et al. (2001, 2004) studied the basement units of the Haymana Basin. The basement is composed of metamorphic rocks of the Karakaya complex, Jurassic platform carbonates and Upper Cretaceous Ankara ophiolitic melanges. Gökçen (1977), Gökçen and Kelling (1983), and Çetin et al. (1986) worked on the sedimentology of the Haymana Basin. These authors mainly observed the sedimentary provenance, structures, and palaeocurrent directions. They suggested a single source area with two different lithologies and provided evidence of a $\mathrm{N}$ to $\mathrm{S}$ feeding direction, and an $\mathrm{E}$ to $\mathrm{W}$ palaeoflow direction was determined by Çetin et al. (1986) for the middle Eocene units. Sirel (1975), Ünalan et al. (1976), Sirel and Gündüz (1976), Meriç and Görür (1981), Sirel et al. (1986), Dellaloğlu and Aksu (1991), Özcan and Altıner (1997), Özcan et al. (2001), and Özcan (2002) performed palaeontology studies on the Upper Cretaceous to Eocene basin fill of the Haymana Basin. Görür et al. (1984, 1998), Koçyiğit et al. (1988, 2003), and Koçyiğit (1991) suggested fore-arc type development for the evolution of the basin by comparing the tectonic position and stratigraphic record of the Haymana Basin with other Central Anatolian basins.

Before the total closure of the İzmir-Ankara Ocean and related oceans, the Palaeocene palaeogeographical setting around Ankara was a shallow- to deep-marine environment that was mainly characterised by reefal, platform limestones, and flyschoidal sediments extending from Polatl, Haymana, Tuzgölü, Ankara, and Çankırı that were deposited on top of the accreted North Anatolian ophiolitic masses. Finally, a vast collection of tectonically controlled Tertiary basins were filled by shallow-marine to molassic to fluvial to lacustrine deposits mostly interbedded with volcanics/ volcaniclastics. Later, continental deposition in fluvial to lacustrine environments became predominant in Central Anatolia during the Plio-Quaternary (Şengör and Yılmaz 1981 and Çeliker 2009).

The tectonic faults are mostly developed in the SW-NE and NW-SE directions (Fig. 1). The E-W extending and symmetric Haymana Anticline is observable with a length of $18 \mathrm{~km}$. The Haymana Formation is the best outcrop of the Haymana Anticline (Arikan 1975).

The Haymana Basin is a NW-SE-trending sedimentary basin located in Central Anatolia. The basement of the Haymana Basin is characterised by the Kırşehir metamorphic and crystalline magmatic (granitoid) rocks, the Mollaresul Formation (massive limestones), and the Mesozoic Ankara Complex (ophiolitic melange) (e.g. Rigo de Righi and Cortesini 1959; Arikan 1975). The sediments in the basin range in age from the Upper Cretaceous to the Pliocene with dominantly marine characteristics (e.g. Rigo de Righi and Cortesini 1959; Arikan 1975; Ünalan et al. 1976; Turgut

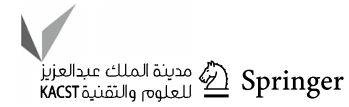


1978; Görür et al. 1984, 1998; Ayyıldız 2001). Seismic data suggest that the thickness of the sediments in the basin is $7000 \mathrm{~m}$ or more.

In the Haymana Basin, the Kartal Formation is composed of red conglomerates, sandstones, and marl, with nodular carbonate deposited in a fluvial environment. The Haymana Formation is represented mainly by fining-upward sequences composed mainly of grey-coloured conglomerate, coarse sandstone and shale alternations. The Beyobası Formation consists of sandstone and conglomerates. The medium- to thick-bedded, abundant algal- and fossil-bearing limestone unit is usually referred to as the Çaldag Formation. The Yeşilyurt Formation consists of bioclastic limestone and blocky marl. In the western part, the Palaeocene clastic unit is named the Kirkkavak Formation, and it consists of conglomerates, sandstones, and algal limestones at the base and turbiditic sandstone and grey marl alternations. The Eskipolatll Formation is composed of thin-bedded grey sandstones and marls with limestones. By the middle Eocene, the sediments graded vertically and laterally into the shallow-marine nummulitic yellow-beige limestones and marl of the Çayraz Formation. The Ilgınlıkdere Formation consists of grey conglomerates and sandstone. The Beldede Formation consists of red conglomerate, sandstone, and marl. The Yamak Formation is composed of grey conglomerate and sandstone marl (Fig. 3).

\section{Depositional environment of the Haymana Formation}

The Haymana Formation was first named by Rigo de Righi and Cortesini (1959), and the same terminology was used in the study. The unit is exposed around Haymana village and covers large areas in the south of the study area (Fig. 2).

The Haymana Formation is generally composed of conglomerate channel fill at the base, followed by yellow sandstone and bituminous black shale alternation. The conglomerates and sandstones show various base structures and gradations, and the sandstones are generally fine- and medium-coarse-grained and classified as arkose according to McBride's classification (McBride 1963).

We measured three stratigraphic sections (L1, L2, and L3) around Haymana village (Fig. 2). According to our surface observations, sedimentation was controlled by turbidity currents with at least two sets of thick, conglomerate, conglomerate-sandstone, and sandstone-shale alternation deposits at the base of fining-upward sequences possibly resulting from abrupt activities of submarine fans. In the study, sedimentological studies of the Haymana Formation sandstones identify a submarine fan in the Haymana Basin. The part of the study is confined to outcrop samples from the submarine-fan sandstones (the L1, L2, and L3 measured sections) and focuses depositional controls on reservoir properties of the Haymana Formation sandstones. Lithology, sedimentary structure, and textures within three measured sections (L1, L2, and L3) of the Haymana sandstone facies were determined by a visual examination on the surface. Analysis of the lithology, texture, and sedimentary structure of the outcrop samples allow separation of the Haymana Formation sandstones into three distinct lithofacies, A, B, and C.

The first section (L1, Lithofacies A) is represented mainly by fining-upward sequences composed mainly of conglomerate, coarse sandstone, and shale alternations. A thick, sandy, matrix-supported conglomerate layer forms the base of the formation and contains rounded to semi-rounded, poorly graded (maximum $3 \mathrm{~cm}$ in diameter) conglomerates. In addition, laminated sandstone layers, homogeneous sandstones, and shale alternations (turbidites) form $\sim 70 \%$ of the section. They are mainly represented by yellow, medium-grained sandstone layers, with structures such as flute casts (locally), some ripple, and parallel laminations, but mostly cross-stratification, and burrows, and black shales; slumps are also observed. Previous sedimentological study on the sandstone layers of the unit was performed by Çetin et al. (1986). They also suggested, based on the primary sedimentary structures and tectono-sedimentary classification of the sandstone grains, a NNW to SSE dominant palaeocurrent direction and intra- or fore-arc environment for the deposition of the unit. The second measured section (L2, Lithofacies B) shows characteristics similar to those of the first section if one considers the source and deposition direction. The layers of L2 consist of sandstone-shale alternations. Sedimentation was controlled by turbidity currents with at least two sets of thick conglomerate, conglomerate-sandstone, and sandstone-shale alternation deposits at the base of finingupward sequences possibly resulting from abrupt activities of submarine fans (Fig. 4). We proposed the sedimentological model for Haymana Formation sandstones in the Haymana Basin (Fig. 4). The third measured section (L3, Lithofacies C) shows structures similar to those of the others. L3 contains thin-bedded $(<25 \mathrm{~cm})$, very fine-grained sandstone layers with structures such as flute casts, parallel laminations, black shale, and burrows. The age of the formation is suggested to be Maastrichtian on the basis of benthic and pelagic fossil assemblages (Ünalan et al. 1976; Sirel 1975).

In the study area, the Haymana Formation sandstones may be separated into Lithofacies A, Lithofacies B, and Lithofacies $\mathrm{C}$ based on the lithology and structure (Fig. 5, Table 1). Sedimentary structures and lithofacies characteristics such as laminated, burrows, parallel to subparallel geometry, slumps, and load and flute casts, etc. were determined on the surface. 
Fig. 4 Depositional environments of the Haymana Formation submarine-fan sandstones

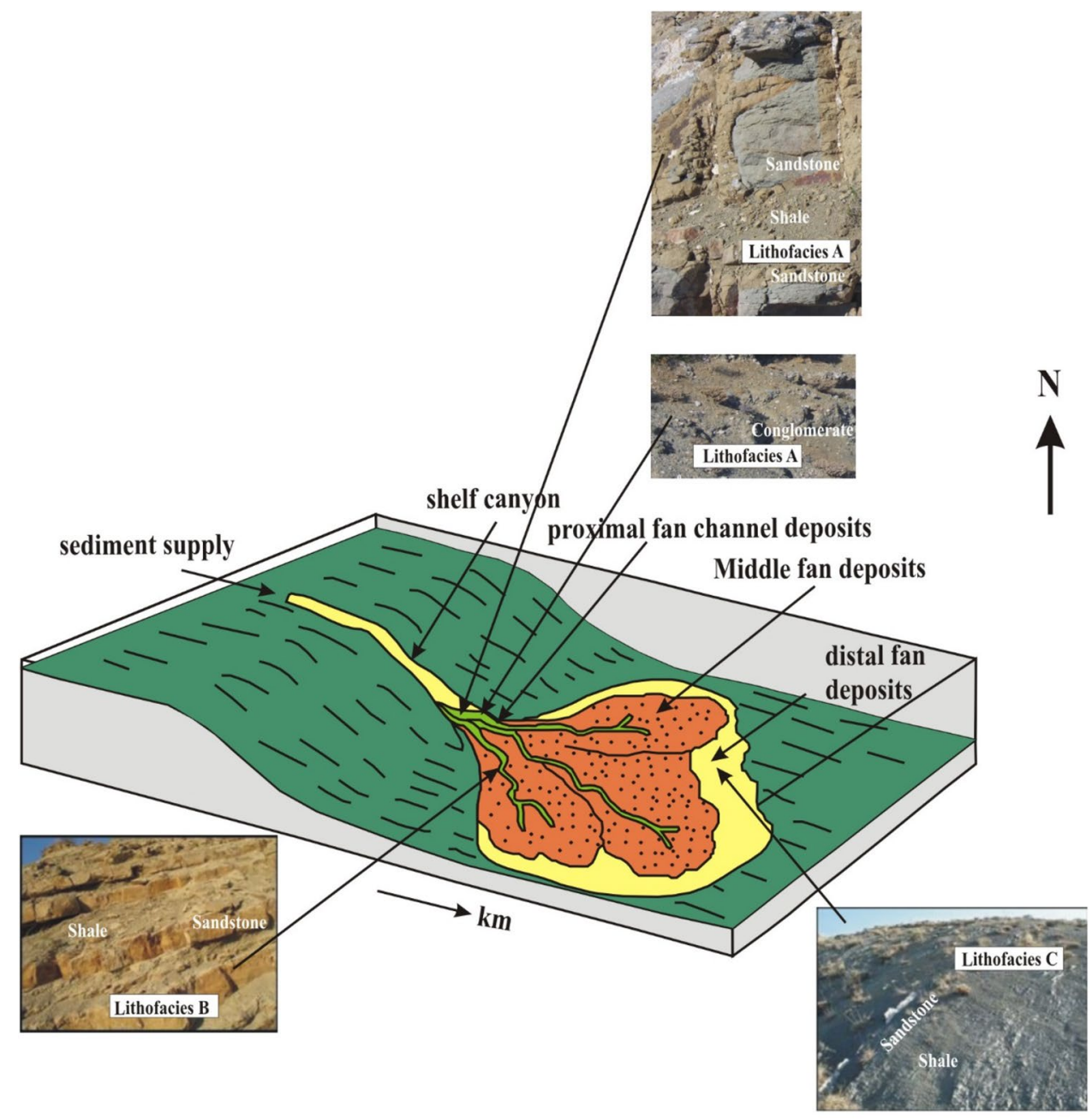

No scale

Lithofacies A consists of clean, parallel-laminated, mostly cross-stratified, moderate-well sorted, medium- to coarse-grained, upward-fining yellow sandstones with bituminous black shales, and subrounded, occasional burrows. The porosity and permeability are good. These characteristics suggest deposition via turbidity currents in the proximal part of the submarine fan.

Lithofacies B also contains bituminous black shale and yellow sandstone, and this unit has a finer grain size than the Lithofacies A. Lithofacies B mostly contains parallel-laminated, well-bedded, fine-grained, moderately sorted, arkosic sandstones. The Lithofacies B zone contains an abundance of sedimentary structures such as laminated, burrows. These characteristics suggest deposition via turbidity currents in the middle of the submarine fan. Detrital grains are subangular and subrounded. The permeability is low, and the porosity is moderate.

Lithofacies $\mathrm{C}$ contains very fine-grained yellow sandstones and bituminous black shales. The major lithofacies characteristics are parallel to subparallel geometry, laminated shale, slumps, and load and flute casts.

These characteristics suggest deposition via turbidity currents in the distal part of the submarine fan in a lowenergy and nonreservoir environment.

The Haymana Formation consists of foraminifera fossils (Tritaxia trilatera Cushman, Dorothia bulletta Carsey, Dorothia eseicona Reuss, Blumina carseyae Plummer, Bolivina incrassata Reuss, Guadryine cretacea Karrer, Quadrimorphina allomorphinoides Reuss, Globotruncana arca Cushman, Globotruncana conica White, Globotruncana stuarti De Lapparent, Globotruncana elevata Brotzen, and Heterolepa vortex White). According to these fossils, the age of the Haymana Formation is Upper Cretaceous (Ünalan et al. 1976; Sirel 1975). 


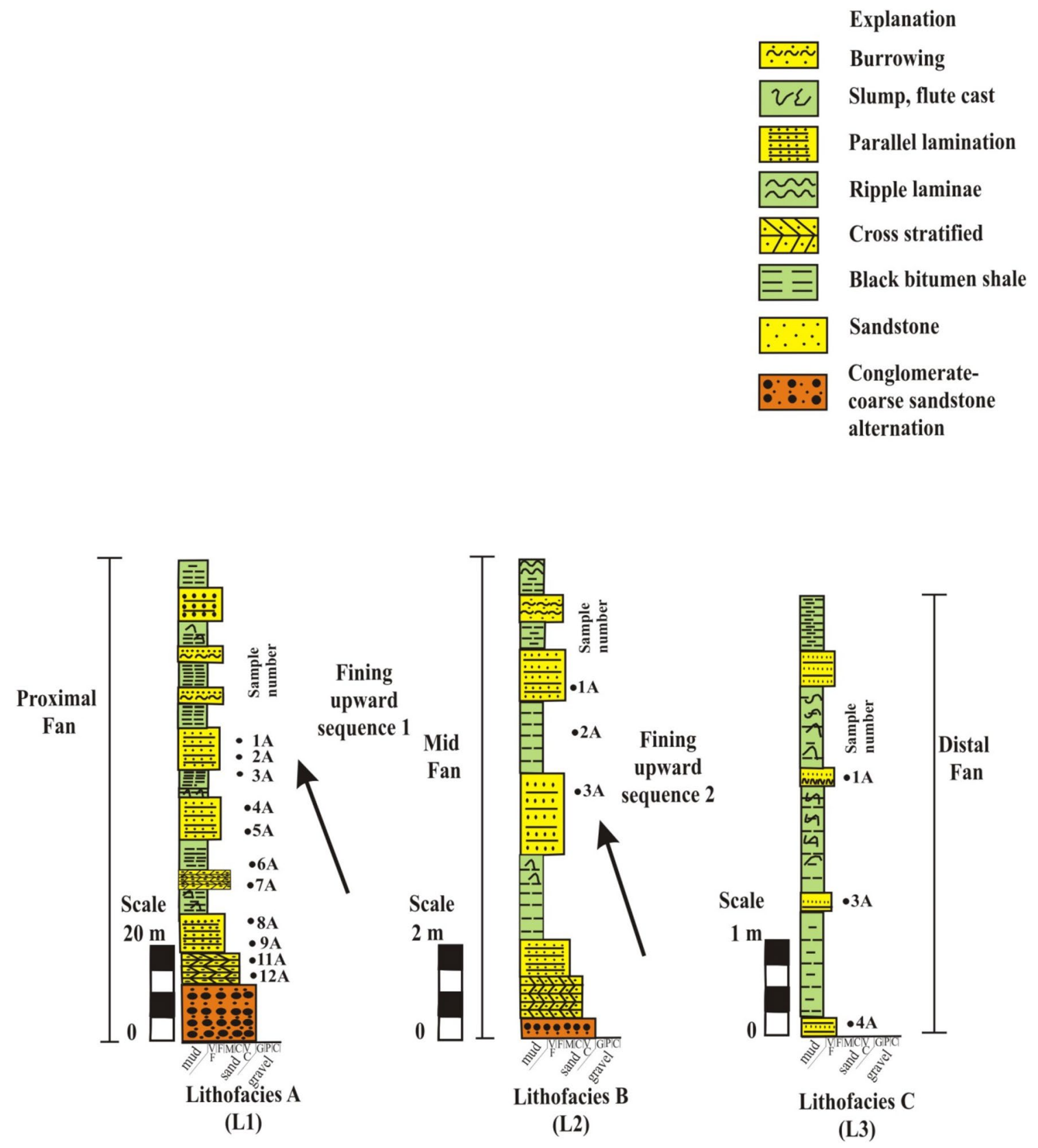

Fig. 5 Measured stratigraphic sections of the Haymana Formation

\section{Materials and methods}

We measured three stratigraphic sections (L1, L2, and L3) around Haymana village and collected outcrop samples. Lithology, sedimentary structure, and textures within three measured sections (L1, L2, and L3) of the Haymana sandstone facies were determined by a combination of visual examination (on the surface) and optical microscopy (in the laboratory). Forty-five outcrop sandstone samples from these sections (L1, L2, and L3) of the Haymana Formation sandstones were collected and studied. Sandstone petrography

and mineralogy were determined in 40 thin sections by 300 point counts in the laboratory.

The mineral composition of the studied samples was determined by X-ray powder diffraction (XRD) (PW-1730, Philips, Eindhoven, Netherlands) at the University of Aveiro laboratories. All samples were ground gently for $5 \mathrm{~min}$ in a porcelain ball mill prior to measurement. Mineralogical analyses of the samples were performed on randomly oriented samples (total fraction) and on the clay $(<2 \mu \mathrm{m})$ fraction. The clay fraction was obtained by gravitational sedimentation of the samples. XRD analyses were performed on eight oriented samples of 
Table 1 Lithofacies A-B-C are given based on the lithology and structure of the Haymana Formation sandstones

\begin{tabular}{|c|c|c|c|}
\hline Lithofacies & Major Facies Attributes & Processes Involved & Paleoenvironment \\
\hline \multicolumn{4}{|l|}{ Lithofacies A } \\
\hline Conglomerate, sandstone-shale & $\begin{array}{l}\text { Parallel lamination, mostly cross } \\
\text { stratified, medium-good sorted, } \\
\text { medium to coarse grained borrow- } \\
\text { ing sandstones and black bitumen } \\
\text { shales, foraminifera }\end{array}$ & $\begin{array}{l}\text { Sandy high density turbidity } \\
\text { current evolving into debris } \\
\text { flow }\end{array}$ & Proximal part of the submarine fan \\
\hline \multicolumn{4}{|l|}{ Lithofacies B } \\
\hline $\begin{array}{l}\text { Fine grained sandstones-shale } \\
\text { alternating }\end{array}$ & $\begin{array}{l}\text { Mostly parallel laminated, fine } \\
\text { grained moderately sorted and } \\
\text { black bitumen shales, ripple lami- } \\
\text { nation, foraminifera }\end{array}$ & Turbidity current & Middle part of the submarine fan \\
\hline \multicolumn{4}{|l|}{ Lithofacies C } \\
\hline $\begin{array}{l}\text { Very fine grained sandstones-shale } \\
\text { alternating }\end{array}$ & $\begin{array}{l}\text { Parallel to subparallel geometry; } \\
\text { laminated, very thin sandstones } \\
\text { black bitumen shales, slump, load } \\
\text { and flute casts; foraminifera }\end{array}$ & Turbidity current & Distal part of the submarine fan \\
\hline
\end{tabular}

clay particles that were air-dried, ethylene-glycol-saturated, and heated to $500{ }^{\circ} \mathrm{C}$.

The microstructural properties of these samples were determined in detail by a scanning electron microscope (SEM) (JSM-840A, Jeol Europe BV, Nieuw-Vennep, Netherlands) equipped with an energy-dispersive spectroscopy (EDS) analyser (TN-5502, Trocor, the Netherlands). SEM-EDS analyses were performed in the Averio laboratories.

Chemical analysis of the reservoir interval involved Fourier transform infrared (FTIR) spectroscopy. In other research areas, previous reports have mentioned that organic matter is present in the shales and that FTIR spectroscopy can be used to determine the presence of hydrocarbons and the types of minerals in the sample (Shoval and Nathan 2011; Alstadt et al. 2012). Additionally, characterisation of clay minerals by FTIR spectroscopy (Awaja and Bhargava 2006; Breen et al. 2008; Herron et al. 2014) is important for petroleum reservoir studies due to the negative effect of clay minerals on hydrocarbon production in sandstone reservoirs. In this study, the attenuated total reflectance-FTIR (ATRFTIR) method was used for the first time on bituminous sandstone samples of the Haymana Formation. The ATR technique was selected to combat significant problems of infrared analyses, such as sample preparation and spectral reproducibility (Adamu 2010; Udvardi et al. 2014).

In the study A FTIR spectrometer (Nicolet Magna 750, Nicolet Instrument Corporation, Markham, Ontario, Canada) was used to determine the chemical origin of the organic samples, organic structure, and authigenic clay type for bituminous sandstone. FTIR analyses were performed at the University of Aveiro laboratories for eight surface samples.

Porosity and permeability analyses for 45 surface samples from the Haymana sandstones were conducted to interpret reservoir quality. Porosity was measured using a helium gas expansion porosimeter, and permeability was measured using a Temco RCH series model permeameter at the Middle East Technical University laboratories. The sandstone samples were prepared as standard core plugs $2.5 \mathrm{~cm}$ in diameter and 5-6 cm in length.

A mercury capillary pressure apparatus was used to measure the pore diameter in six fragment samples. Mercury pressure tests were performed at the Middle East Technical University laboratories by using fragment samples approximately $13 \mathrm{~mm}$ in diameter and $10-25 \mathrm{~mm}$ in length.

\section{Results}

\section{Petrographic analysis}

Petrographic analyses of selected outcrop samples were used to separate the Haymana Formation sandstones into three distinct lithofacies (A-B-C). The Haymana Formation sandstones are arkose according to McBride's classification (McBride 1963).

The Lithofacies A sandstones exhibit medium-coarsegrained (0.4-0.6 mm), moderate-well sorted, subrounded arkosic grains and have an average porosity of $20-25 \%$ (Fig. 6a, b, c).

Mineralogically, the detrital grains in the Lithofacies A sandstones are predominantly quartz (59\%), feldspar (30\%; mostly plagioclase), and sedimentary, and volcanic fragments $(15 \%)$. Pore-filling components are authigenic chlorite (14\%, Fig. 6d) and smectite- illite (6\%). Carbonate cement also occurs in scattered patches, occasionally completely filling pores as an early calcite cement $(32 \%$, 

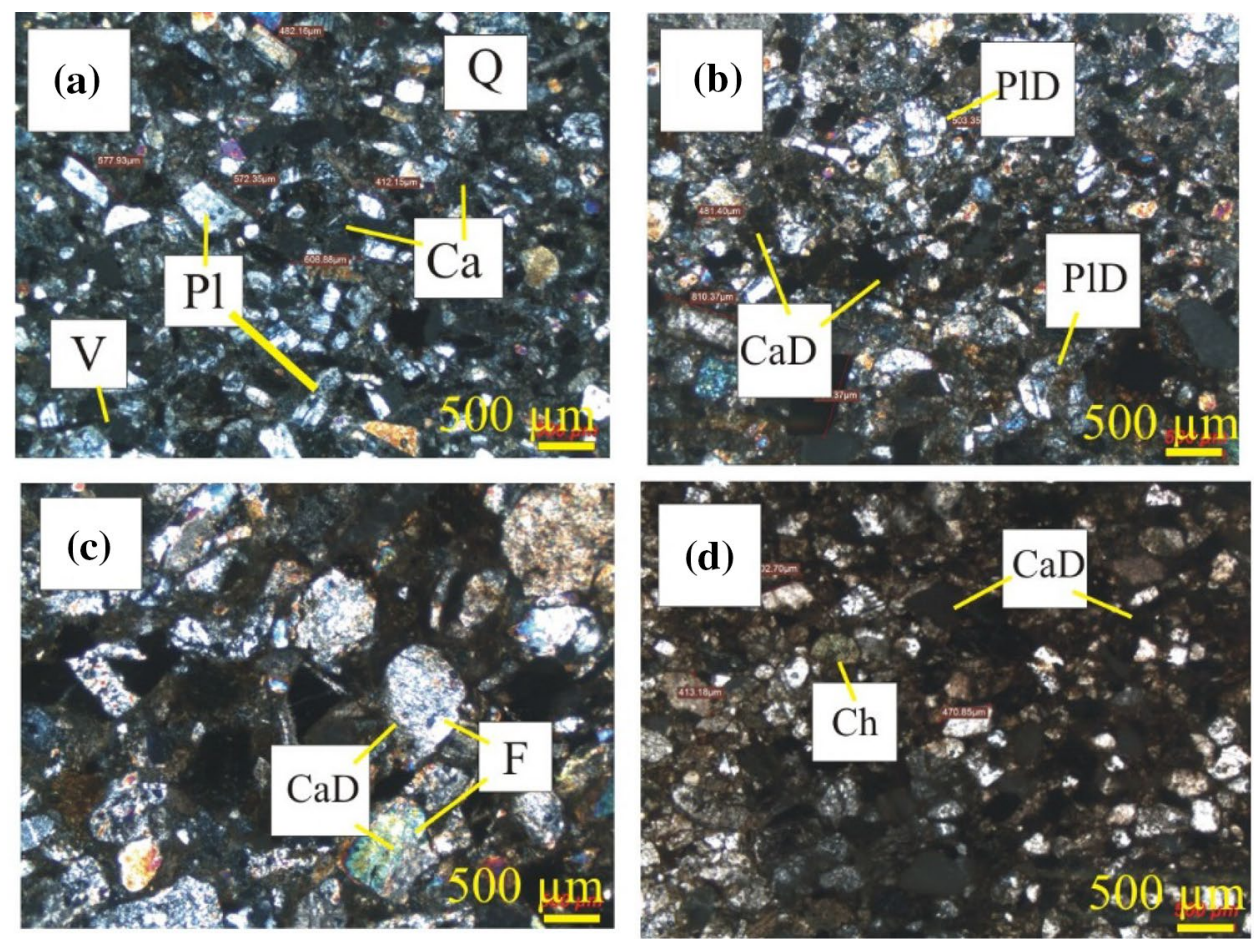

Fig. 6 Micrographs of the Haymana Formation sandstones (Lithofacies A sandstones) a Arkose is observed in the photo. Carbonate cement (Ca) (Early calcite) is seen. Carbonate cement occurs in scattered patches, occasionally completely filling pore as a early calcite cement. Q: Quartz, Pl: Plagioclase, V: Volcanic rock, L1 section, Sample number: 1A. b Dissolution of the Carbonate cement $(\mathrm{CaD})$ and plagioclase (PID) is common. L1 section, Sample number: 5A.

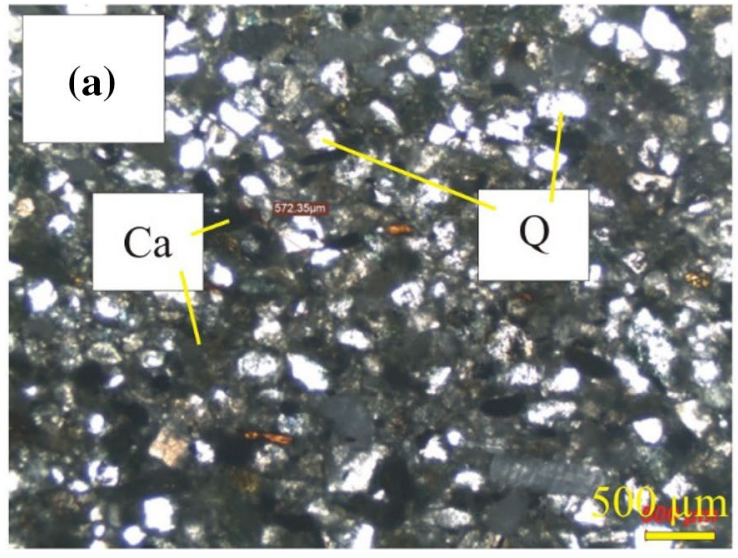

Fig. 7 Micrographs of the Haymana Formation sandstones. a Lithofacies B sandstones are fine grain size $(0.2 \mathrm{~mm})$, and moderately sorting, subangular-subrounded grains. Carbonate cement occurs

Fig. 6a). Lithofacies A may have experienced dissolution of late calcite cement (Fig. 6b, d).

The Lithofacies A sandstones exhibit large and clean pores. The pore shapes are highly variable and display c Medium-coarse grain size $(0.4-0.6 \mathrm{~mm})$, medium sorting, subrounded (Lithofacies A sandstones). Extensive carbonate cement development which partially replaced by feldspar (F) grains, Feldspars are commonly honeycombed from dissolution. L1 section, Sample number: $5 \mathrm{~A}$. d Authigenic chlorite mineral is seen as a pore-filling, Dissolution of the Carbonate cement $(\mathrm{CaD})$. L1 section, Sample number: $11 \mathrm{~A}$

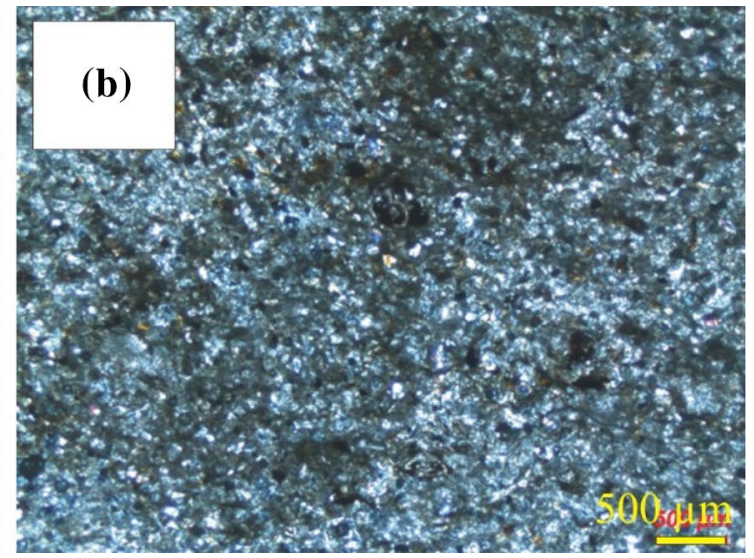

completely filling pore as a early calcite cement (Ca). Q: Quartz, L2 section, Sample number $1 \mathrm{~A}, \mathbf{b}$ thin grain size $(0.112 \mathrm{~mm})$ of the Lithofacies C sandstones, L3 section, Sample number 4A

dissolution features in some portions of the sandstones (Fig. 6b, c).

The Lithofacies B sandstones exhibit fine-grained $(0.2 \mathrm{~mm})$, moderately sorted, subangular-subrounded arkosic grains, and have porosities of $4-6 \%$ (Fig. 7a). 
Fig. 8 Representative SEM micrographs and EDS traces for Haymana sandstones samples a Diagenetic chlorite (Cs: chamosite) and mixed-layer smectite-illite (I-S) minerals have observed as grain coating mostly. b Diagenetic chlorite minerals have observed as grain coating mostly. The chlorite is an iron-rich. The Lithofacies A sandstones exhibit large pores with diameter $2-4 \mu \mathrm{m}$. Lithofacies A sandstones, L1 section, Sample number 5A
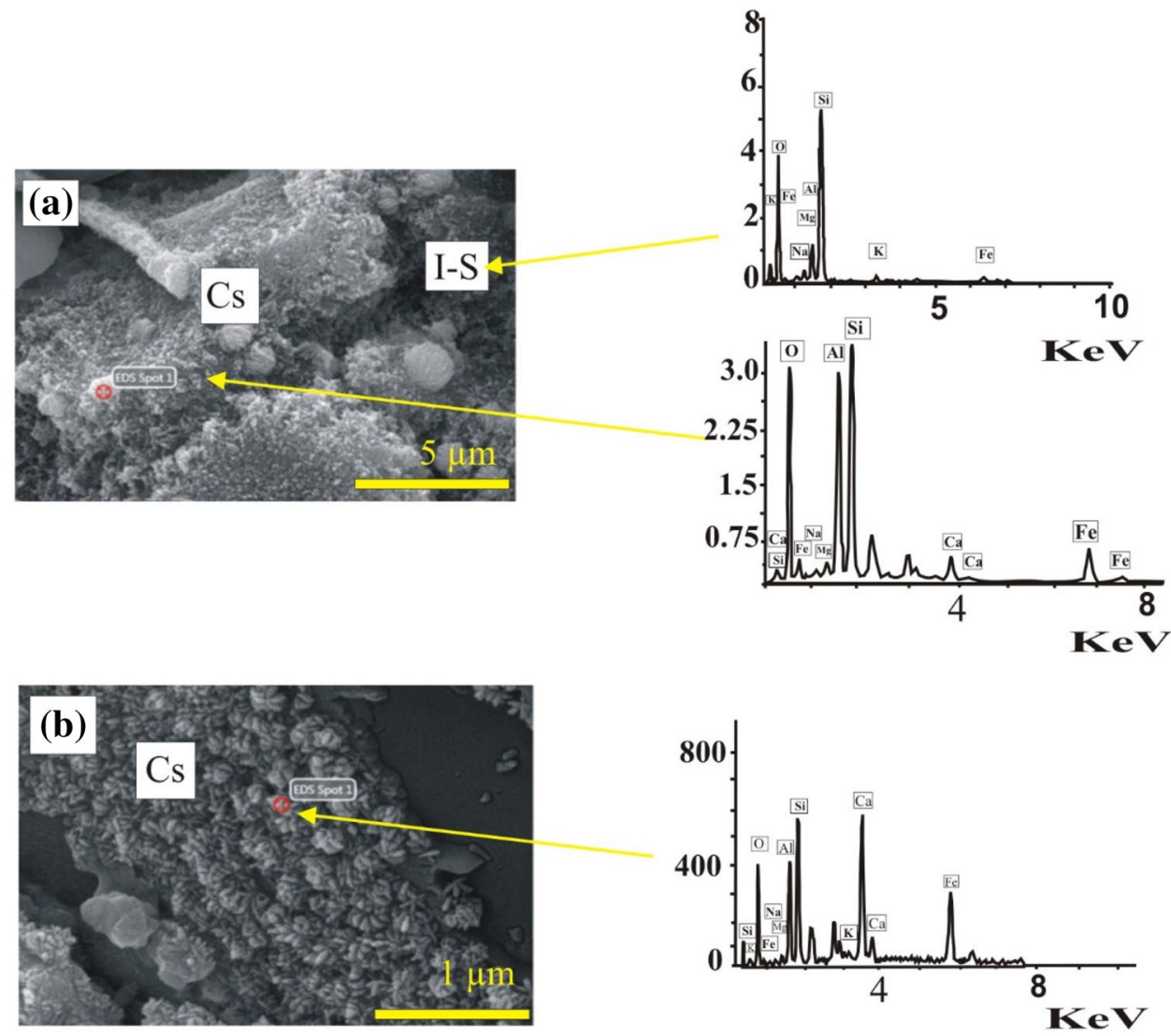

Mineralogically, the detrital grains in the sandstone facies are predominantly quartz (55\%), feldspar (30\%; mostly plagioclase), and sedimentary, and volcanic rock fragments (15\%). Matrix components include detrital muscovite and biotite (2\%), authigenic chlorite $(25 \%)$, and smectite (16\%). Carbonate cement also occurs completely filling the pores as an early calcite cement (34\%, Fig. 7a).

The Lithofacies $\mathrm{C}$ sandstones are very fine-grained and poorly sorted $(0.112 \mathrm{~mm})$. These units do not show reservoir characteristics (Fig. 7b).

Diagenetic chlorite minerals were observed as grain coatings in the Lithofacies A sandstones, and the chlorite is iron-rich (chamosite) (Fig. 8a, b). Additionally, diagenetic mixed-layer illite/smectite minerals were observed as grain coatings in the Lithofacies A sandstones (Fig. 8a). Hence, the Lithofacies A sandstones exhibit larger (pores with diameters of 2-4 $\mu \mathrm{m}$ ) and cleaner pores than the Lithofacies B sandstones (Figs. 8a, b, 9a). The feldspars are commonly honeycombed (Fig. 6c).

Primary pores and pore throats are commonly filled with authigenic clays (smectite 16\%, illite 29\%), creating microporosity (pores with diameters $<1.5-2 \mu \mathrm{m}$ ) in the Lithofacies B sandstones (Fig. 9a).

Diagenetic chlorite minerals $(\mathrm{Ch})$ were observed as thin flakes in the Lithofacies C sandstones (Fig. 9b). Abundant clay minerals and very small grain sizes cause poor-quality reservoirs in the Lithofacies $\mathrm{C}$ sandstones.

\section{Diagenetic history}

The most important diagenetic phases of the Haymana Formation sandstones are quartz overgrowth, feldspar, calcite, smectite, chlorite, mixed-layer illite-smectite, and illite. These diagenetic phases are given in order of their paragenetic sequence as determined by petrographic analysis (Fig. 10).

The foregoing discussion provides evidence demonstrating that fluids that were modified by diagenesis in the shale passed into the overlying sandstone and exerted significant influence on its diagenesis. In this discussion, we review the paragenetic events and the distribution of authigenic products. Quartz overgrowth cementation was an unimportant stage of diagenesis that rarely appeared in thin sections of Lithofacies A and Lithofacies B of the Haymana sandstones (Figs. 6a, 7a). Quartz overgrowth is not detectable by scanning electron microscopy. Early calcite cement appears to be exclusive, and evidence for the early formation of calcite cement is primarily textural (Fig. 6a). First, clastic grains frequently appear to be "floating" in the cement (Fig. 6a), and these clastic grains seem to be matrix supported. Secondary porosity occurs via late calcite cement (Fig. 6b, c, 

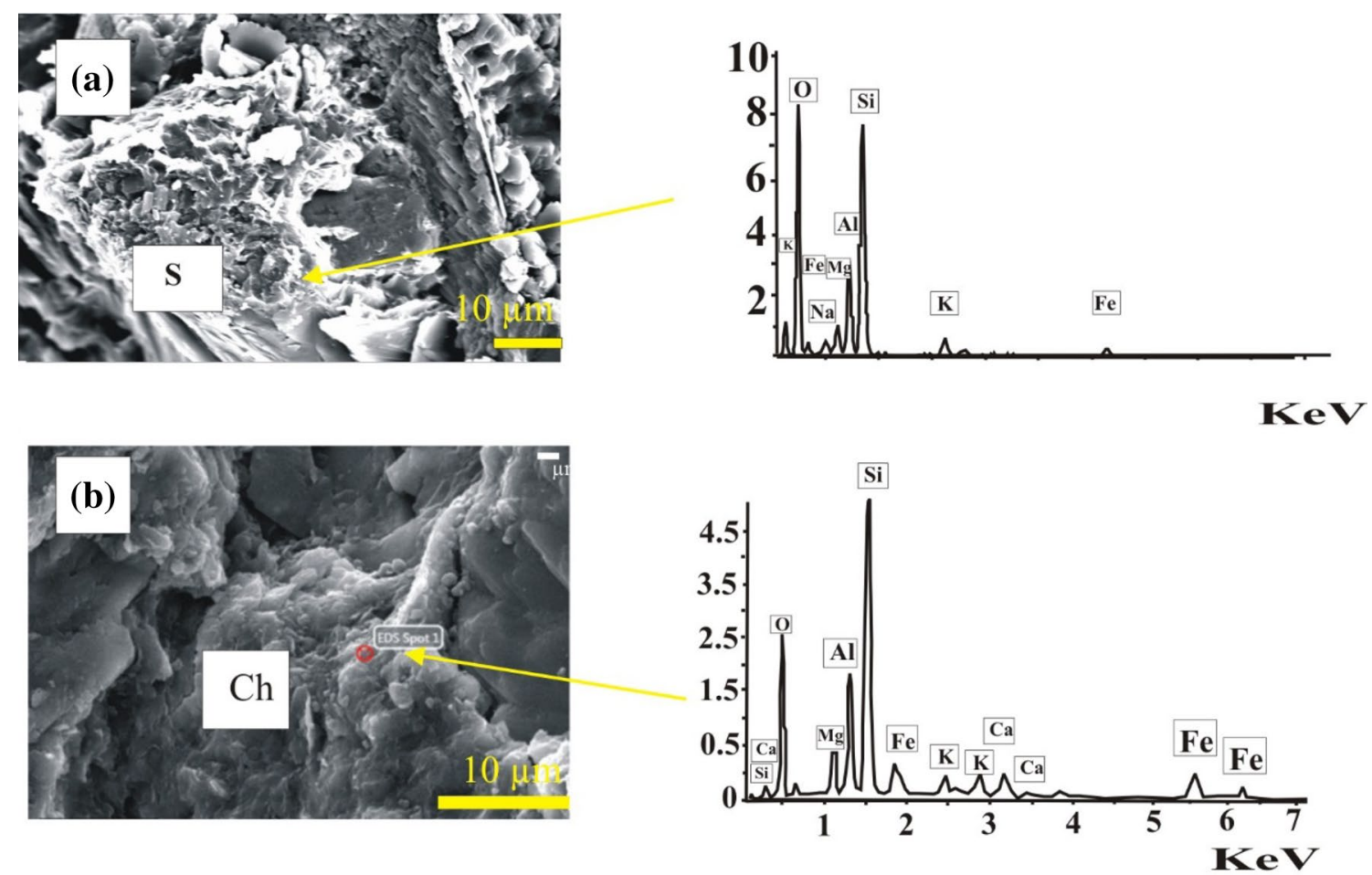

Fig. 9 Representative SEM micrographs and EDS traces for Haymana sandstones samples a Diagenetic smectite minerals $(S)$ have observed as pore filling. Pore throats are commonly filled with authigenic clays, creating microporosity (pores with diameter $<1.5-2 \mu \mathrm{m}$ ).

d) in the late diagenetic stage. Additionally, K-feldspar and plagioclase are dissolved in thin sections (Fig. 6c).

Chlorite is present in the Lithofacies $\mathrm{C}$ sandstone as thin flakes (Fig. 9b). According to EDS examination, the chlorite (chamosite) is iron-rich (Fig. 8a, b) and formed as a result of expulsion of chlorite components from the shale. Chlorite cementation was a major porosity-reducing event. After these last stages of quartz (minor) and chlorite cementation, porosity was commonly reduced to $3 \%$ (from thin section porosity for Lithofacies A sandstones).

An important increase in the amount of illite (29\%) and mica in the Lithofacies B sandstones was observed. XRD clay analyses (Supplementary Information; minerals were abbreviated from Whitney and Evans 2010) of Lithofacies B sandstone samples show a low primary smectite content (16\%). Lithofacies A sandstones, however, may have a high smectite content (30\%).

Carbonate cementation and clay cementation are among the most damaging diagenetic processes for petrophysical properties, especially for Lithofacies B, apart from locally important occurrences of chlorite (25\%). In contrast, Lithofacies A has less chlorite (14.5\%) than Lithofacies B. Hence, diagenetic minerals negatively affected the Lithofacies B sandstones. The Lithofacies A sandstones constitute the

Lithofacies B sandstones, L2 section, Sample number 2A. b Diagenetic chlorite minerals $(\mathrm{Ch})$ have observed as thin flakes. Lithofacies $\mathrm{C}$ sandstones, L3 section, Sample number 4A

main reservoir in the light of all the diagenetic developments in the Haymana Basin.

\section{Spectral analysis}

In this study, we analysed bituminous sandstone samples by FTIR analyses using the ATR technique (Fig. 11). The FTIR evaluation was performed according to Van der Marel and Beutelspacher (1976). The IR spectrum of the Lithofacies A section 5A sample shows structural hydroxyl peaks at 3700 and $3620 \mathrm{~cm}^{-1}$ (Fig. 11c). The peak at $3430 \mathrm{~cm}^{-1}$ corresponds to $\mathrm{OH}$ stretching of water. $\mathrm{OH}$ deformation of water was observed at $1635 \mathrm{~cm}^{-1}$. Si-O stretching of quartz was observed at $777 \mathrm{~cm}^{-1}$. The peak at $461 \mathrm{~cm}^{-1}$ corresponds to Si-O-Si deformation. Aromatic CH (1160, 1110 and $1030 \mathrm{~cm}^{-1}$ ) peaks are shown in Fig. 11c.

The structural hydroxyl peaks at 3700, 3620, and $3565 \mathrm{~cm}^{-1}$ were observed in the IR spectrum of the Lithofacies B section 1A sample (Fig. 11b). The $\mathrm{OH}$ band at $3565 \mathrm{~cm}^{-1}$ pertains to $\mathrm{FeFeOH}$ grouping. This result is in concordance with the XRD and SEM-EDS results. Si-O stretching of quartz and feldspar was observed at 778 and $642 \mathrm{~cm}^{-1}$, respectively. The peak at $3425 \mathrm{~cm}^{-1}$ corresponds to $\mathrm{OH}$ stretching of water, and $\mathrm{OH}$ deformation of water was observed at $1635 \mathrm{~cm}^{-1}$. Aromatic C-H $(1182,1105$, 
Fig. 10 Diagenetic sequence of the Haymana Formation of the Haymana Basin

\section{Diagenetic Summary

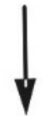

Early calcite cementation

Early Diagenesis

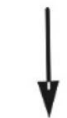

Feldspar

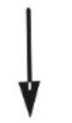

Smectite

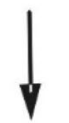

Mixed layer illite-smectite

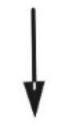

Illite

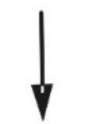

Chlorite

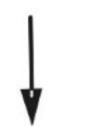

Quartz overgrowth<smiles>COCCO</smiles>

Late Diagenesis

\section{Dissolution of the feldspar and late calcite cementation porosity}

and $1030 \mathrm{~cm}^{-1}$ ) peaks are shown in Fig. 11b. The peaks at 527,464 , and $430 \mathrm{~cm}^{-1}$ correspond to Al-O-Si deformation, $\mathrm{Si}-\mathrm{O}-\mathrm{Si}$ deformation, and $\mathrm{Si}-\mathrm{O}$ stretching, respectively.

The IR spectrum of the Lithofacies $\mathrm{C}$ section 4A sample shows a single $\mathrm{OH}$ peak at $3446 \mathrm{~cm}^{-1}$ in the $\mathrm{OH}$ stretching region (Fig. 11a). OH deformation of water was observed at $1635 \mathrm{~cm}^{-1}$, and $\mathrm{Si}-\mathrm{O}$ stretching of quartz was observed at $777 \mathrm{~cm}^{-1}$, similar to Fig. $11 \mathrm{~b}$, c. The peak at $461 \mathrm{~cm}^{-1}$ corresponds to Si-O-Si deformation. Aromatic CH (1205, 1125 and $1065 \mathrm{~cm}^{-1}$ ) peaks are shown in Fig. 11a. The peak near $648 \mathrm{~cm}^{-1}$ corresponds to $\mathrm{Mg}_{3} \mathrm{OH}$. The main hydrocarbon functional groups recorded in the samples are the aromatic $\mathrm{C}-\mathrm{H}$ bonds (Fig. 11a-c). Permeability values in Lithofacies A sandstones of the Haymana Formation are generally several orders of magnitude higher than those in Lithofacies B sandstones of the Haymana Formation according to the permeability measurements. The absorbance of the hydrocarbon peaks is much higher in the less permeable Lithofacies B compared to the more permeable Lithofacies A according to the FTIR analyses. In the study, an inverse relationship between the absorbance of hydrocarbon functional groups and permeability was observed.

\section{Reservoir implication}

Lithofacies $\mathrm{C}$ exhibits the poorest reservoir quality of the Haymana sandstones as a result of the very fine grain size, poor sorting, and abundant clay cement.

Most of the porosity in the Lithofacies A sandstones is primary intergranular, and a small amount of the porosity 


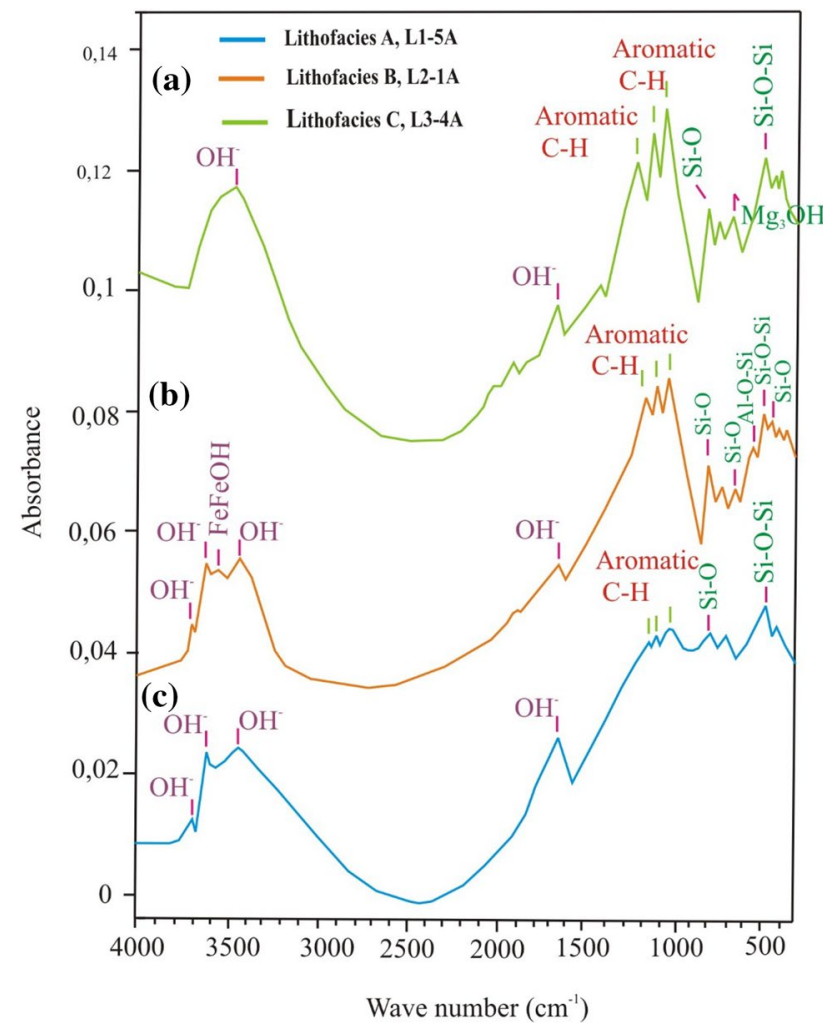

Fig. 11 The FTIR spectra of (a) Lithofacies C section 4A sample (b) Lithofacies B section 1A sample (c) Lithofacies A section 5A sample of Haymana Formation

is secondary intergranular and intragranular. Thus, Lithofacies A sandstones have high reservoir potential. Depositional pore geometries have been altered by carbonate cement precipitation (early calcite cement) in the primary pores, and subsequent leaching of carbonate has enlarged the pores. Secondary porosity formed through the dissolution of calcite and feldspar, and dissolution of calcite and silicate minerals produced approximately $3 \mathrm{vol} \%$ secondary porosity. However, secondary porosity is not commonly detectable by scanning electron microscopy.

Permeabilities differ significantly between the Lithofacies $\mathrm{A}$ and $\mathrm{B}$ sandstones. The best permeability occurs in the Lithofacies A unit and can be related to the large grain size, the presence of cross-bedding, the low amount of authigenic clays or cements in the pore throats, and the enlarged pore apertures. Thus, the Lithofacies A sandstone permeability ranges from 80 to $120 \mathrm{mD}$. By contrast, the Lithofacies B sandstones contain variable yet smaller pore and pore-throat sizes, which are affected by pore-filling authigenic clays, smaller grain sizes, and no dissolution. Thus, the permeability of the Lithofacies B sandstone ranges from 16 to 35 $\mathrm{mD}$, which is lower than that of the Lithofacies A sandstone. Moderate grain sorting, the presence of deformable grains, and matrix pore fill also reduce the effective porosity of

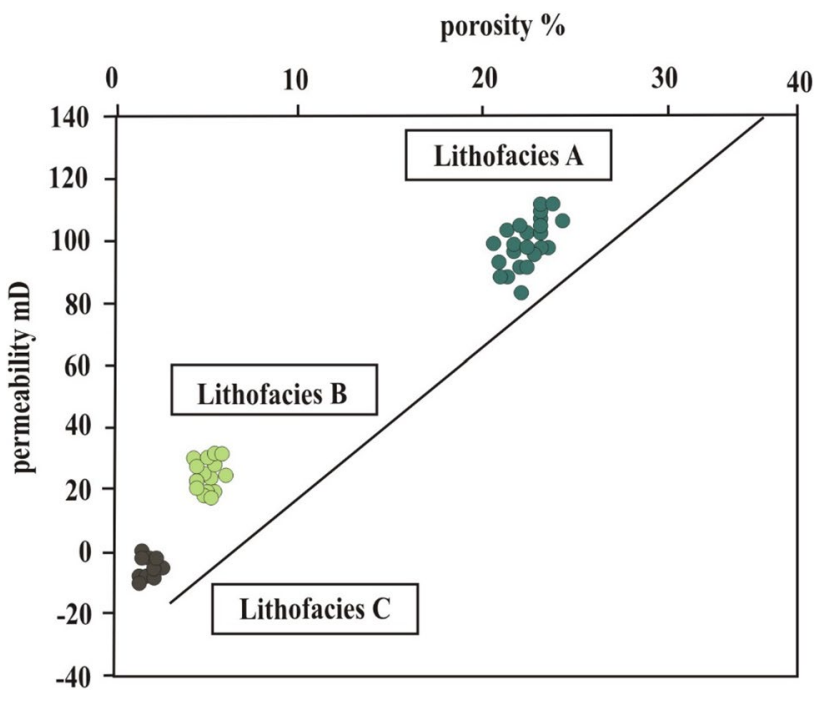

Fig. 12 Cross-plot porosity and permeability of representative samples from the Haymana Formation

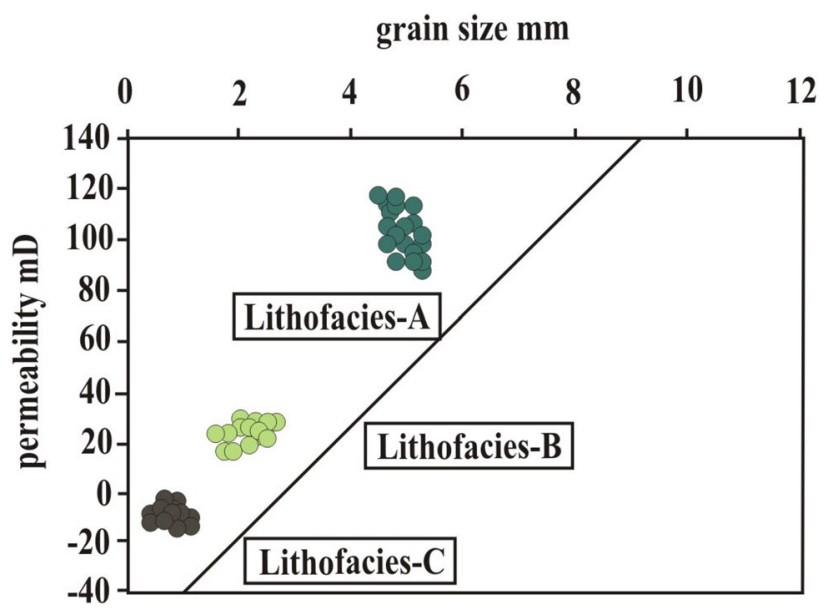

Fig. 13 Cross-plot grain size and permeability of representative samples from the Haymana Formation

Lithofacies B (average porosity of 4-6\%). In contrast, Lithofacies A sandstones have high porosities (average 20-25\%), and most pore throats (50\% or more) range between 1 and $4 \mu \mathrm{m}$. According to these data, Lithofacies A sandstones show good reservoir characterisation.

The permeability in the Haymana sandstones of the Haymana Basin (especially Lithofacies A) is strongly correlated with porosity (Fig. 12). The permeability is mainly controlled by grain-coating and pore-filling diagenetic cements. Petrographic and SEM analyses confirm that pore-filling diagenetic cements significantly influence permeability in the Lithofacies B sandstones. In addition, the relative importance of grain size in controlling permeability in the Haymana sandstones was assessed by petrographic analysis (Fig. 13). Permeability and porosity were reduced 
Fig. 14 Mercury-capillary curves of sandstones of Haymana Formation

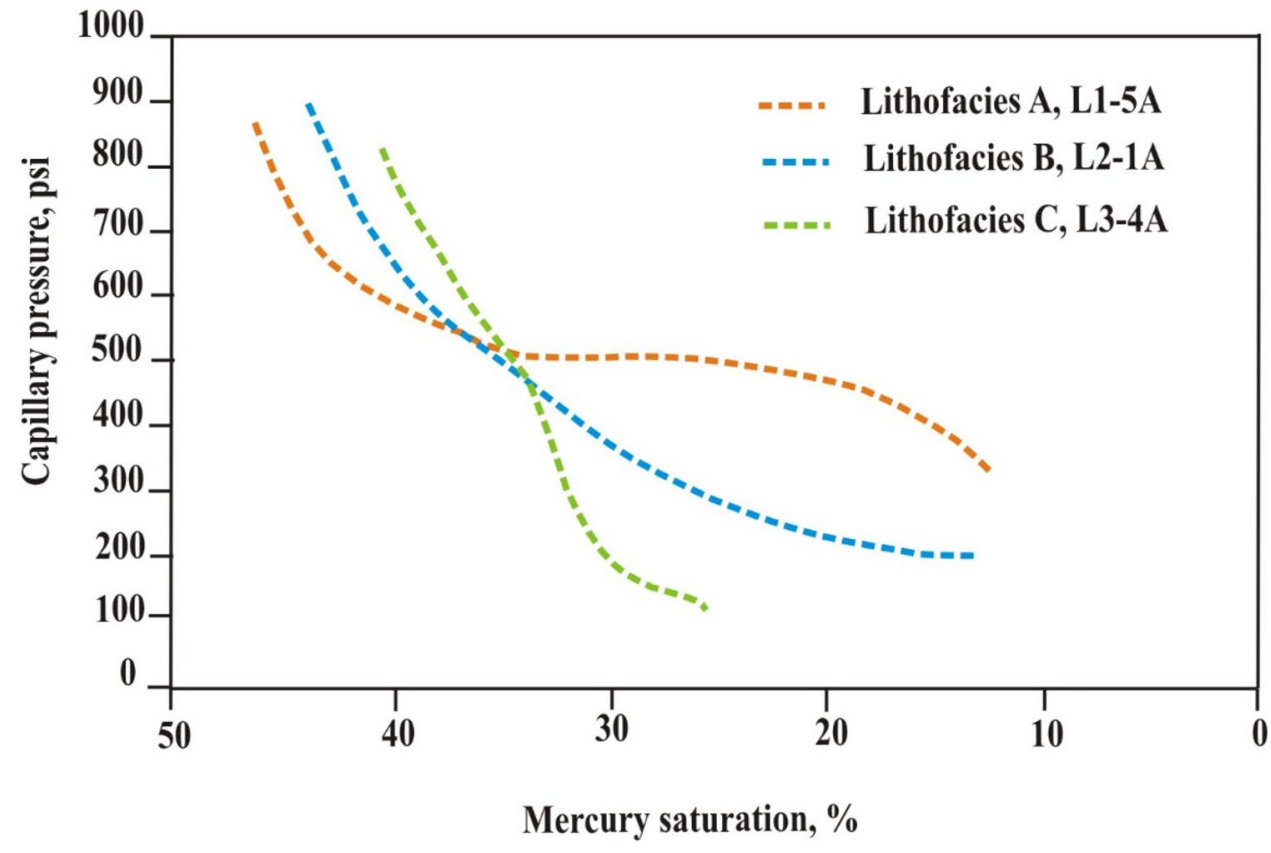

in the Lithofacies B sandstones compared with the Lithofacies A sandstones. Grain size is determined by the energy of the depositional rather than diagenetic environment, and grain size controls the permeability in the Lithofacies B sandstones because of the more abundant laminations and the lower settling velocities. Lithofacies B sandstones are associated with smaller sand sizes, and the Lithofacies A sandstones, which are coarser grained and contain fewer diagenetic cements than the Lithofacies B sandstones, have the highest permeability in the Haymana sandstones. The high permeabilities of the Lithofacies A sandstones are $k>80$ $\mathrm{mD}$.

This finding is supported by mercury injection testing, where Lithofacies B sandstone samples experienced greater permeability reduction. Capillary pressure data can provide information about pore size distribution in reservoir rocks because mercury injection capillary pressures are proportional to pore-throat radii (Vavra et al. 1992). Pore-throat sizes smaller than $0.5 \mu \mathrm{m}$ are defined as microporosity (Pittman 1979), which does not contribute significantly to permeability. The capillary pressure curves of the Lithofacies A sandstones of the Haymana Formation are parallel to the $X$-axis (Fig. 14), and compared with the Lithofacies B sandstones of the Haymana Formation, Lithofacies A possesses high permeabilities. The capillary pressure curves of the Lithofacies B sandstones are weakly parallel to the $X$-axis (Fig. 14) and have small median pore-throat sizes $($ mean $=1.52 \mu \mathrm{m})$ and low porosities (average 4-6\%). Lithofacies A sandstones have larger pore-throat sizes $($ mean $=2.06-3 \mu \mathrm{m})$ and higher porosities (average $20-25 \%$ ) than Lithofacies B, and most pore throats (50\% or more) range between 1 and $4 \mu \mathrm{m}$. According to these data, the
Lithofacies A sandstones of the Haymana Formation show intermediate-good reservoir characterisation. The capillary pressure curves of the Lithofacies $C$ sandstones are subparallel to the $Y$-axis.

\section{Discussion}

The best effective porosity occurs within the Lithofacies A sandstones due to the medium-coarse grain size, moderategood sorting, fewer clay minerals, and secondary pores by dissolution of carbonate cement and feldspar. The Lithofacies A sandstone has average core porosities of 20-25\%, whereas the Lithofacies B sandstone has average porosities of 4-6\%. Moderate grain sorting, small grain size, the presence of deformable grains, and matrix pore fill will reduce the effective porosity. The Lithofacies B sandstones consist of moderately sorted, small, subroundedsubangular grains, and pores filled with diagenetic clays, with less exposure to pore-fluid flow. These sandstones contain variable yet small pores that are affected by porefilling authigenic clays, and the permeabilities range from 16 to $35 \mathrm{mD}$.

The permeabilities differ significantly between the Lithofacies A and B Haymana sandstones. The best permeability occurs in the Lithofacies A unit and can be related to the larger grain size, the presence of cross-bedding, the small amount of authigenic clays or cements in the pore throats, and the enlarged pore apertures. The Lithofacies A sandstone permeabilities range from 80 to $120 \mathrm{mD}$. By contrast, the Lithofacies B sandstones contain variable yet smaller pore and pore-throat sizes, which are affected by pore-filling 
authigenic clays, smaller grain sizes, and no dissolution. The Lithofacies B sandstone permeabilities range from 16 to 35 $\mathrm{mD}$. Lithofacies A sandstones have larger pore-throat sizes $($ mean $=2.06-3 \mu \mathrm{m})$ and high porosities (average 20-25\%). Most pore throats (50\% or more) range between 1 and $4 \mu \mathrm{m}$. According to these data, Lithofacies A sandstones show good reservoir characterisation.

Grain size controls the permeability in the Lithofacies $B$ sandstones because of the laminations and low settling velocities. Additionally, Lithofacies B sandstones are associated with small grain sizes. Lithofacies A sandstones, which are coarser grained and contain fewer diagenetic cements than the Lithofacies B sandstones, have the highest permeability in the Haymana sandstones. The high permeabilities of Lithofacies A sandstones are $k>80 \mathrm{mD}$.

According to this study, the proximal sandstones of the submarine-fan complex of the Haymana Formation may contain high-potential reservoirs in the Haymana Basin. To date, no significant deposits of hydrocarbons have been discovered in this sandstone, although intensive exploratory work towards this end has been carried out in the Haymana Basin. In this basin, hydrocarbon is sourced from deep zones of the NW, E, and NE Haymana Basin and may be capped by the Haymana sandstones (Ates et al. 2005). According to our study, the Lithofacies B sandstones of the Haymana Formation are not suitable as diagenetic traps for hydrocarbon exploration in the Haymana Basin. However, the Lithofacies A sandstones of the Haymana Formation may be expected to have the highest exploration success.

\section{General petroleum assessment of the Haymana Basin and nearby basins}

Haymana Basin is located in Central Anatolia (south of Ankara city) and covers approximately $4000 \mathrm{~km}^{2}$. The Haymana Basin is one of the most important Mesozoic (Upper Cretaceous) basins in Central Anatolia (Fig. 1). Although the evolutionary history of the basin is directly connected with crystalline rocks of the Pontide, Tauride, and Kırşehir blocks, only the Pontide basement is exposed in the study area, while the Kırşehir or Tauride basement bounds the basin in the east and south without any direct contact. The basement units exposed in the study area cover small areas with respect to basin fill and generally have tectonic contact with the younger units in the north and south. In contrast to the complex structure of the basement units, the basin fill was continuously deposited from the Upper Cretaceous to Upper Eocene time interval and is basically represented by continental clastic rocks, shallow-marine limestones and turbidites. The basin fill and the basement units are unconformably covered by Neogene continental clastics or evaporites.
The units exposed in the Haymana Basin can be primarily grouped as (1) basement, (2) Upper Cretaceous to Eocene basin fill, and (3) Neogene cover.

The pioneering reservoir studies of the Upper Cretaceous sandstones in Central Anatolia were conducted by Sonel et al. (2009) and Büyükutku and Sarı (2011). Although the main aim of these studies was to reveal the petroleum potential of the basin, no significant deposits of hydrocarbons have been discovered in these sandstones.

In this basin, sedimentation was controlled by turbidity currents with conglomerate, conglomerate-sandstone, and sandstone-shale alternation deposits at the base of finingupward sequences, possibly resulting from abrupt activities of submarine fans. According to this study, the submarinefan complex may be the most important type of petroleum reservoir in the Haymana Basin. Therefore, the presence of oil-saturated deep channels in the turbidite-bearing Haymana Formation has palaeogeographic significance and will also attract the attention of oil companies searching for commercial oil in unexposed parts of the Haymana Basin. Also, oil-saturated channel fill, which has a thickness range of 1-5.90 m, occurs in the turbidite-bearing Haymana Formation of the Haymana Basin (Şenalp and Gökçen 1978).

The tectonic faults are mostly developed in the SW-NE and NW-SE directions (Fig. 1). The E-W extending and symmetric Haymana Anticline (ENE of the Haymana vicinity) is observable with a length of $18 \mathrm{~km}$, and the Haymana Formation is the best outcrop of the Haymana Anticline (Arikan 1975).

The basin fill was continuously deposited from the Upper Cretaceous to Upper Eocene time interval and is basically represented by continental clastic rocks, shallow-marine limestones, and turbidites. Seismic data suggest that the thickness of the sediments in the basin is $7000 \mathrm{~m}$ or more. Early exploration activities in the Haymana Basin started in the 1960s, commenced by MTA (General Directorate of Mineral Research and Exploration). MTA drilled one exploration well approximately $2500 \mathrm{~m}$ deep to the Haymana Anticline core in the NE Haymana Basin. Log determinations and preliminary reports concerning this well are sealed (Aynur Buyukutku's post doctorate study).

We have publications that describe the reservoir rock properties of the Salt Lake Basin and Ereğli-Ulukışla Basin, particularly the Upper Cretaceous units (Fig. 1).

Framework petrographic and provenance studies on the Upper Cretaceous sandstones of the Ereğli-Ulukışla Basin in the Central Anatolian Province of Turkey indicate that the sediments are generally derived from recycled orogenic sources and fold-thrust belt fields. The Haymana Formation (Upper Cretaceous) is time equivalent to the Çiftehan Formation. The average porosity of the Çiftehan Formation ranges from 1.96 to $5 \%$. Permeability values of less than 
$1 \mathrm{mD}$ indicate that these sandstones display poor reservoir quality (Sonel et al. 2009).

The Salt Lake Basin contains depositional turbiditic, marine, and lithic Upper Cretaceous sandstones (Haymana Formation) in the Yakacık vicinity. Porosities of the Haymana Formation sandstones in the Salt Lake Basin range up to $28.5 \%$, while the permeability is mostly less than $0.01 \mathrm{mD}$ (Büyükutku and Sarı 2011). According to the core porosity of the reservoir, the quality of the sandstones of the Haymana Formation is fair to good, with porosities ranging from 13.50 to $28.50 \%$. Authigenic minerals tend to reduce overall permeability because the intergranular pore networks become clogged by cement in the Haymana sandstones. In addition, dissolution processes have slightly enhanced porosity in some samples. However, dissolution does not increase reservoir permeability; consequently, porosity slightly increases reservoir quality.

In this study, oil shows from the Upper Cretaceous Haymana sandstones in the proximal parts of the submarine fan were reported in the Haymana Basin. However, locally generated hydrocarbon extracts suggest that these Haymana Formation shales are over mature, producing gas with total organic carbon $(\mathrm{TOC})=0.09-0.21 \%, T_{\max }=478-498$, and OI $($ oxygen index $)=47-143$ (Ferzankaya 2007). Hydrocarbon may have been generated in deep zones around the NW, NE, and E Haymana vicinity (Ates et al. 2005).

To date, no significant deposits of hydrocarbons have been discovered in these sandstones, although intensive exploratory work towards this end has been carried out in Central Anatolia. In this study, Lithofacies B sandstones of Haymana Formation are not suitable as diagenetic traps for hydrocarbon exploration in the Haymana Basin. However, the Lithofacies A sandstones of the Haymana Formation may be expected to have the highest exploration success (proximal parts of the submarine fan of the Haymana Formation).

\section{Conclusions}

The Haymana Formation sandstones are arkose according to McBride's classification (McBride 1963). The most important diagenetic phases of the Haymana Formation sandstones are quartz overgrowth, feldspar, calcite, smectite, chlorite, mixed-layer illite-smectite, and illite.

The sandstones of the Haymana Formation may be classified into three lithological units on the basis of lithology, sedimentary structure, texture, and petrography as Lithofacies $\mathrm{A}, \mathrm{B}$, and $\mathrm{C}$.

In the study, the petrophysical parameters (porosity, permeability, and capillary pressure) of the Haymana Formation sandstones are determined to interpret reservoir quality. The Lithofacies A sandstone has average core porosities of $20-25 \%$, and Lithofacies B has average porosities of $4-6 \%$. The Lithofacies A sandstone permeabilities range from 80 to $120 \mathrm{mD}$, and the Lithofacies B sandstone permeabilities range from 16 to $35 \mathrm{mD}$. Lithofacies B sandstones have small median pore-throat sizes $($ mean $=1.52 \mu \mathrm{m})$, and Lithofacies A sandstones have larger pore-throat sizes $($ mean $=2.06-3 \mu \mathrm{m})$. According to these data, the sandstones of the Haymana Formation show intermediate-good reservoir characterisation, and the Lithofacies A sandstones have high reservoir potential.

FTIR analyses of the samples reveal that the main hydrocarbon functional groups present are aromatic $\mathrm{C}-\mathrm{H}$ bonds. Permeability values in Lithofacies A are generally several orders of magnitude higher than those in Lithofacies $\mathrm{B}$ according to the permeability measurements. The absorbance of the hydrocarbon peaks is much higher in the less permeable Lithofacies B compared to the more permeable Lithofacies A according to the FTIR analyses. In the study, an inverse relationship between the absorbance of hydrocarbon functional groups and permeability was observed.

The Lithofacies A unit contains larger grain sizes, cross-bedding, a small amount of authigenic clays or cements in the pore throats, and enlarged pore apertures. In contrast, the Lithofacies B sandstones contain variable yet smaller pore and pore-throat sizes, which are affected by pore-filling authigenic clays, small grain size, and no dissolution. Lithofacies $\mathrm{C}$ exhibits the poorest reservoir quality of the Haymana sandstones as a result of very fine grain size, poor sorting, and abundant clay cement.

In the study area, Lithofacies B sandstones of the Haymana formation are not suitable as diagenetic traps for hydrocarbon exploration in the Haymana Basin. But Lithofacies A sandstones of the Haymana Formation may be suitable as diagenetic traps for hydrocarbon exploration, and these sandstones may be expected to have the highest exploration success (proximal parts of the submarine fan of the Haymana Formation).

Acknowledgements This study forms part of the master thesis of Mithat Emre Kibrıs, which is conducted in Ankara University by the supervision of Dr. Aynur BÜYÜKUTKU. Thesis was carried out by Erasmus programme signed between Ankara University and New Lisbon University. The authors thank to Aveiro laboratories very much for making the analyses available.

Open Access This article is distributed under the terms of the Creative Commons Attribution 4.0 International License (http://creativeco mmons.org/licenses/by/4.0/), which permits unrestricted use, distribution, and reproduction in any medium, provided you give appropriate credit to the original author(s) and the source, provide a link to the Creative Commons license, and indicate if changes were made. 


\section{References}

Adamu MB (2010) Fourier transform infrared spectroscopic determination of shale minerals in reservoir rocks. Niger J Basic Appl Sci 18:6-18

Alstadt KN, Katti DR, Katti KS (2012) An in situ FTIR step-scan photoacoustic investigation of kerogen and minerals in oil shale. Spectrochim Acta A Mol Biomol Spectrosc 89:105-113

Arıkan Y (1975) Tuz gölü havzasının jeolojisi ve petrol imkanları. M.T.A Dergisi 85:17-38

Ates A, Bilim F, Büyüksaraç A (2005) Curie point depth investigation of Central Anatolia, Turkey. Pure Appl Geophys 162:357-371

Awaja F, Bhargava S (2006) The prediction of clay contents in oil shale using DRIFTS and TGA data facilitated by multivariate calibration. Fuel 85:1396-1402

Ayyıldız T (2001) Organic facies characteristics in the Paleocene shale of the northern part of the Tuz Gölü Basin, Central Anatolia, Turkey. Energy Sources 23(8):727-737

Batman B (1978) Haymana kuzeyinin jeolojik evrimi ve yöredeki melanjın incelenmesi-stratigrafi birimleri, Hacettepe University. Earth Sci 4:95-124

Breen C, Clegg F, Herron MM, Hild GP, Hillier S, Hughes TL, Jones TGJ, Matteson A, Yarwood J (2008) Bulk mineralogical characterisation of oilfield reservoir rocks and sandstones using Diffuse Reflectance Infrared Fourier Transform Spectroscopy and Partial Least Squares analysis. J Pet Sci Eng 60:1-17

Büyükutku A, Sarı A (2011) The Diagenesis of Haymana Sandstones (Upper Cretaceous), Yakacik Vicinity, Northwest of Ankara (Salt Lake Basin), Turkey. Energy Sources Part A Recovery Util Environ Eff 33(9):795-804

Çeliker GD (2009) Post-paleogene deformation in Northernmost Tip of Tuzgölü Fault (Paşadağ, South of Ankara) Turkey. The Graduate School of Natural and Applied Sciences of Middle East Technical University, $73 \mathrm{pp}$

Çetin H, Demirel İH, Gökçen SL (1986) Haymana'nın (SW Ankara) doğusu ve batısındaki Üst Kretase-Alt Tersiyer istifinin sedimantolojik ve sedimanter petrolojik incelemesi. TJK Bülteni 29(2):21-33

Chaput E (1932) Observations géologiques en Asie Mineure: Le Crétacé supérieur dans l'Anatolie Centrale. CRAS 194:1960-1961

Chaput E (1935a) L'Eocene du plateau de Galatie (Anatolie Centrale). CRAS 200:767-768

Chaput E (1935b) Les plissements Tertiare de l'Anatolie Centrale. CRAS 201:1404-1405

Chaput E (1936) Voyages d'études géologiques et géomorphologiques en Turquie. Mém. Inst. Francais D’Archaéo. İstanbul, II, 312 pp

Ciner A, Deynoux M, Koşun E (1996) Cyclicity in the middle eocene Yamak turbidite complex of the Haymana basin, Central Anatolia, Turkey (1:100,000). Geol Rundsch 85:670

Dellaloğlu AA, Aksu R (1991) Ankara-Temelli-Haymana-KuluKırıkkale arasındaki alanın jeolojisi ve petrol olanakları. TPAO rapor no.3006 (Unpublished)

Ferzankaya M (2007) Petroleum potential of the Haymana formation (Central Anatolia) by sequence stratigraphic. Institute of science, Ms thesis, $90 \mathrm{pp}$

Gökçen SL (1977) Sedimentology and provenance of resedimented deposits in part of the Haymana basin-Central Anatolia. Yer bilimleri 3:13-23

Gökçen SL, Kelling G (1983) The Paleogene Yamak sand-rich submarine fan complex, Haymana basin, Turkey. Sediment Geol $34: 219-243$

Görür N, Oktay FY, Seymen I, Şengör AMC (1984) Palaeotectonic evolution of the Tuzgölü basin complex, Central Turkey: sedimentary record of a Neo-Tethyan closure. J Geol Soc Lond Spec Publ 17(1):467-482
Görür N, Tüysüz O, Şengör AMC (1998) Tectonic evolution of the central Anatolian basins. Int Geol Rev 40(151):831-850

Herron MM, Loan M, Charsky AM, Herron SL, Pomerantz AE, Polyakov M (2014) Kerogen content and maturity, mineralogy and clay typing from DRIFTS analysis of cuttings or core. Petrophysics 55:435-446

Koçyiğit A (1991) An example of an accretionary forearc basin from Central Anatolia and its implications for the history of subduction of Neo-Tethys in Turkey. Geol Soc Am Bull 103:22-36

Koçyiğit A, Özkan S, Rojay B (1988) Examples of the forearc basin remnants at the active margin of northern Neo-Tethys: development and emplacement ages of the Anatolian Nappe, Turkey. J Pure Appl Sci 3:183-210

Koçyiğit A, Winchester JA, Bozkurt E, Holland G (2003) Saraçköy Volcanic Suite: implications for the subductional phase of arc evolution in the Galatean Arc Complex, Ankara-Turkey. Geol J 37:1-14

McBride EF (1963) A classification of common sandstones. J Sediment Pet 33:664-669

Meriç E, Görür N (1981) Haymana-Polatlı havzasındaki Çaldağ kireçtaşının yaş konağı. MTA Bülteni 93:155

Özcan E (2002) Cuisian orthophragminid assemblages (Discocyclina, Orbitoclypeus and Nemkovella) from the Haymana-Polatlı Basin (Central Turkey): biometry and description of two new taxa. Eclogae Geol Helv 95:75-97

Özcan E, Altıner SÖ (1997) Late Campanian-Maastrichtian evolution of orbitoid foraminifera in Haymana basin succession (Ankara, Central Turkey). Rev Paléobiol 16(1):271-290

Özcan E, Sirel E, Özkan-Altıner S, Çolakoğlu S (2001) Late Paleocene Orthophragminae (foraminifera) from the Haymana-Polatlı Basin, Central Turkey, $157 \mathrm{pp}$

Pettingill HS, Weimer P (2002) Worldwide deepwater exploration and production. Lead Edge 21:371-376

Pittman ED (1979) Porosity, diagenesis, and productive capability of sandstone reservoirs. In: Scholle PA, Schluger PR (eds) Aspects of diagenesis, Special Publication-Society of Economic Paleontologists and Mineralogists, vol 26, pp 159-173

Reckamp JU, Özbey S (1960) Petroleum geology of Temelli and Kuştepe structures, Polatlı area. Pet. İş. Gen. Md., Ankara

Rigo de Righi M, Cortesini A (1959) Regional studies in central Anatolian basin. Progress Report 1, Turkish Gulf Oil Co., Pet. İş. Gen. Md., Ankara, $159 \mathrm{pp}$

Rojay B, Yalınız K, Altıner D (2001) Age and origin of some pillow basalts from Ankara mélange and their tectonic implications to the evolution of northern branch of Neotethys, Central Anatolia. Turkish J Earth Sci 10(3):93-102

Rojay B, Altıner D, Özkan Altıner S, Önen P, James S, Thirwall M (2004) Geodynamic significance of the Cretaceous pillow basalts from North Anatolian Ophiolitic Melange Belt (Central Anatolia, Turkey): geochemical and paleontological constrains. Geodin Acta 17(5):349-361

Schmidt GC (1960) AR/MEM/365-266-367 sahalarının nihai terk raporu. Petrol İşleri Genel Müdürlüğü Ankara

Şenalp M, Gökçen SL (1978) Sedimentological studies of the oilsaturated sandstones of the Haymana Region (SW Ankara). Bull Geol Soc Turkey 21:87-94

Şengör AMC, Yılmaz Y (1981) Tethyan evolution of Turkey. A plate tectonic approach. Tectonophysics 75:181-241

Shoval S, Nathan Y (2011) Analyzing the calcination of sulfur-rich calcareous oil shales using FT-IR spectroscopy and applying curvefitting technique. J Therm Anal Calorim 105:883-896

Sirel E (1975) Polatlı (GB Ankara) güneyinin stratigrafisi. TJK Bülteni 18(2):181-192

Sirel E, Gündüz H (1976) Description and stratigraphic distribution of some species the genera Nummulites, Assilina and Alveolina 
from the Ilerdian, Cuisian and Lutetian of Haymana region. TJK Bülteni 19:33-44

Sirel E, Dağer Z, Sözeri B (1986) Some biostratigraphic and paleogeographic observations on the Cretaceous-Tertiary boundary in the Haymana-Polatlı region (Central Turkey). In Walliser O (ed) Global bioevents. Lecture Notes in Earth Sciences, vol 8, pp 385-396

Sonel N, Demirel İH, Sarı A, Büyükutku AG (2009) Petrography, Provenance, and Reservoir Characteristics of the Upper Cretaceous to Middle-Upper Eocene Sandstones in the Ereğli-Ulukışla Basin, Turkey. Pet Sci Technol 27:543-556

Turgut S (1978) Tuz Gölü havzasinin stratigrafik ve çökelsel gelismesi. Türkiye 4. Petrol Kongresi, Bildiriler Kitabi. TPAO, Ankara, 115-126 (in Turkish)

Udvardi B, Kovacs IJ, Kónya P, Földvari M, Füri J, Budai F, Falus G, Fancsik T, Szabó C, Szalai Z, Mihály J (2014) Application of attenuated total reflectance Fourier transform infrared spectroscopy in the mineralogical study of a landslide area, Hungary. Sediment Geol 313:1-14
Ünalan G, Yüksel V, Tekeli T, Gönenç O, Seyirt Z, Hüseyin S (1976) Haymana-Polatlı yöresinin (Güneybatı Ankara) Üst KretaseAlt Tersiyer stratigrafisi ve paleocoğrafik evrimi. TJK Bülteni 19:159-176

Van der Marel HW, Beutelspacher H (1976) Atlas of infrared spectroscopy of clay minerals and their admixtures, 1st edn. Elsevier, Amsterdam, Holland, pp 241-248 and 305-315, 978-0444411877

Vavra CL, Kaldi JG, Sneider RM (1992) Geological applications of capillary pressure: a review. AAPG Bull 76:840-850

Whitney DL, Evans BW (2010) Abbreviations for names of rock-forming minerals. Am Miner 95:185-187

Yüksel S (1970). Etude geologique de la region d'Haymana (Turquie central). Ph.D. Thesis. Fac. Sci. Univ. Nancy, France, 179 pp

Publisher's Note Springer Nature remains neutral with regard to jurisdictional claims in published maps and institutional affiliations. 